\title{
Pelatihan Penggunaan Microsoft Excel untuk Pengolahan Data Pendidikan di SMK Satya Bhakti 2 Jakarta Timur
}

\author{
Endaryono*1, Mahyudi2 $^{2}$, Aswin Saputra ${ }^{3}$ \\ 1,2,3Teknik Informatika, Fakultas Teknik dan Ilmu Komputer, Universitas Indraprasta PGRI Jakarta, \\ Indonesia \\ *e-mail: endaryono612@gmail.com ${ }^{1}$ didimahyudi21@gmail.com ${ }^{2}$ saputraaswin133@gmail.com ${ }^{3}$
}

\begin{abstract}
Abstrak
Pendidikan sebagai bidang yang mengalami perubahan sangat dinamis secara keilmuan terutama dalam bidang teknologi. Perkembangan IT yang mengalami kemajuan setiap detik apabila dapat dimanfaatkan secara maksimal dapat mempermudah segala aktivitas. Mengusai teknologi juga dapat menajadi salah satu kemampuan yang wajib dimiliki para profesional. Apabila mengacu dalam Peraturan Keprofesionalan guru tentang penguasaan IT tidak hanya digunakan sebagai respon perkembangan jaman tetapi juga sebagai kewajiban seorang guru untuk memenuhi kompetensi. Tujuan pelatihan ini agar guru mengusai IT selain meningkatkan kompetensi secara pribadi juga dapat menunjukkan profesionalisme profesinya. Kemampuan IT yang dikuasai oleh guru tidaklah perlu aplikasi yang tinggi, tetapi disesuaikan dengan kebutuhan dasar guru. Pengusaan IT bagi guru lebih ditekankan pada pengusaan aplikasi yang dapat digunakan untuk menyusun administrasi seperti membuat rencana pembelajaran, merekap hasil belajar peserta didik, atau membuat bahan ajar. Berdasarka kebutuhan tersebut aplikasi yang sesuai yaitu microsoft word dan microsoft excel yang dapat mendukung proses pembelajaran terutama dalam menyusun administrasi pembelajaran. Kemampuan peserta dilihat dari penguasaan materi dapat dinilai baik. Hal ini dapat dilihat dari kemampuan para guru dalam kegiatan pelatihan dan praktik berupa pemahaman terhadap rumus-rumus microsoft excel.
\end{abstract}

Kata kunci: Guru Profesional, Microsoft Excel, Pendidikan

\begin{abstract}
Education as a field that is undergoing changes is very dynamic scientifically, especially in the field of technology. The development of IT that is progressing every second if it can be utilized optimally can facilitate all activities. Mastering technology can also be one of the skills that must be possessed by professionals. When referring to the Teacher Professional Regulations regarding mastery of IT, it is not only used as a response to the times but also as a teacher's obligation to fulfill competence. The purpose of this training is for teachers to master IT, apart from improving their personal competence, they can also demonstrate their professional professionalism. The IT skills mastered by the teacher do not need a high application, but are adapted to the basic needs of the teacher. Mastery of IT for teachers is more emphasized on mastering applications that can be used to arrange administration such as making lesson plans, recapitulating student learning outcomes, or making teaching materials. Based on these needs, the appropriate application is Microsoft Word and Microsoft Excel which can support the learning process, especially in preparing learning administration. The ability of participants seen from the mastery of the material can be assessed as good. This can be seen from the ability of teachers in training and practical activities in the form of understanding Microsoft Excel formulas.
\end{abstract}

Keywords: Education, Microsoft Excel, Professional Teacher

\section{PENDAHULUAN}

Salah satu ciri dari revolusi industri 4.0 adalah teknologi menjadi bagian yang tidak terpisahkan dalam kehidupan sehari-hari masyarakat. Dalam tahap ini laju perkembangan teknologi yang sangat pesat dan hampir seluruh aktivitas tidak lepas dari penggunaannya. Pendidikan sebagai bidang yang mengalami perubahan sangat dinamis secara keilmuan terutama dalam bidang teknologi. Perkembangan IT yang mengalami kemajuan setiap detik apabila dapat dimanfaatkan secara maksimal dapat mempermudah segala aktivitas. Mengusai teknologi juga dapat menajdi salah satu kemampuan yang wajib dimiliki para profesional. Apabila mengacu dalam Peraturan Menteri Pendidikan Nasional No. 16 tahun 2007 tentang 
Standar Kualifikasi dan Kompetensi Guru dan Dosen, salah satu kompetensi professional guru ialah memanfaatkan teknologi informasi. Keprofesionalan guru tentang penguasaan IT tidak hanya digunakan sebagai respon perkembangan zaman tetapi juga sebagai kewajiban seorang guru untuk memenuhi kompetensi.

Tujuan guru mengusai IT selain meningkatkan kompetensi secara pribadi juga dapat menunjukkan profesionalisme profesinya. Indikator guru profesional dapat dilihat dari kemampuan beradaptasi dengan perkembangan keilmuan dengan cara menguasai Teknologi Informasi dan Komunikasi (TIK) (Mugara, 2011). Manfaat dari mengusai TIK bagi guru selain memperlihatkan profesionalisme juga dapat membantu dalam proses pembelajaran dan kegiatan administrasi. Seorang guru kelas pada umumnya selain memiliki tugas utama mengajar, tetapi juga memiliki tanggung jawab dalam administrasi yang digunkan untuk mendukung proses belajar mengajar.

Kemampuan IT yang dikuasai oleh guru tidaklah perlu aplikasi yang tinggi, tetapi disesuaikan dengan kebutuhan dasar guru. Pengusaan IT bagi guru lebih ditekankan pada pengusaan aplikasi yang dapat digunakan untuk menyusun administrasi seperti membuat rencana pembelajaran, merekap hasil belajar peserta didik, atau membuat bahan ajar. Berdasarkan kebutuhan tersebut aplikasi yang sesuai yaitu microsoft word dan microsoft excel. Kedua tersebut merupakan aplikasi dasar yang sangat bermanfaat bagi guru dalam mendukung proses pembelajaran terutama dalam menyusun administrasi pembelajaran. Salah satu manfaat penggunaan TIK bagi guru dapat membantu dalam pekerjaan administrasi seperti word processor dan Kebutuhan Tingkat Dasar, spreadsheed (Aka, 2017).

Guru di semua jenjang pendidikan akan selalu memerlukan kemampuan penguasaan aplikasi dasar tersebut khususnya jenjang SMK. Program pembelajaran bagi siswa-siswa SMK, terutama perkantoran memiliki karakteristik mengembangkan seluruh kemampuan anak, sehingga seorang guru SMK dituntut memiliki kemampuan dalam menyusun rencana pembelajaran lebih detil dan terinci agar kegiatan pembelajaran terarah meskipun banyak hal yang harus dicapai. Aplikasi microsoft word akan sangat membantu guru dalam mendokumentasikan rencana pembelajaran dengan kegiatan yang beraneka ragam tersebut. Secara tidak langsung penguasaan guru akan teknologi informasi dapat berdampak bagi peserta didik karena beban guru dalam administrasi berkurang dan terdapat dokumentasi pembelajaran yang utuh sebagai bahan evaluasi.

Kebutuhan akan pengusaaan IT terutama aplikasi microsoft office didasarkan pada permasalahan yang dihadapi hampir setiap guru SMK khususnya pada mitra. Berdasarkan analisis awal diketahui bahwa guru masih kurang mengenal aplikasi yang dapat dimanfaatkan dalam proses adminsitrasi seperti MS words, excel, atau power point. Guru hanya menggunakan aplikasi tersebut terbatas pada tools tertentu seperti menulis tanpa adanya numbering, margin, pengiputan data, atau spasi yang benar. Demikian juga pada aplikasi MS excel, guru masih menggunakan apabila form yang seharusnya dilengkap merupakan file berjenis excel. Khusus untuk pemanfaatan MS power point, guru masih sangat asing untuk memanfaatkan animation, menambahkan link, dan video.

Proses pelatihan dan pembinaan adalah serangkaian tahapan proses peningkatan kualitas kompetensi guru yang harus memiliki pola atau model yang lebih efektif. Model ini tidak hanya mampu secara bertahap mengarahkan peserta pelatihan pada fase kemandirian, tetapi yang terpenting adalah mendorong penyempurnaan kualitas pelatihan dan pembinaan itu sendiri ke arah yang lebih baik. Sehingga untuk dapat mencapai hal tersebut keberadaan model ini juga harus mampu merevitalisasi peran dan fungsi sekolah sebagai tempat untuk saling belajar, tumbuh dan berkembang. (Abdal, 2007) (dalam Supriady, 2019).

Berdasarkan uraian tersebut pengusaan TIK bagi guru SMK khususnya di mitra yaitu SMK Satya Bahkti 2 Jakarta Timur sangat dibutuhkan. Mengingat pengetahuan dan keterampilan ini merupakan respon dari revolusi industri 4.0 sekaligus dapat menjadi tempat untuk meningkatan kemampuan dan keterampilan guru. Melalui pelatihan ini guru diharapkan dapat meningkatkan profesionalisme khusunya dalam penguasaan TIK yaitu pemanfaatan aplikasi MS office dalam administasi pekantoran dan proses pembelajaran. 
Secara umum tujuan kegiatan workshop ini adalah untuk melatih para guru dalam pemanfaatan MS Excel sebagai alat bantu dalam pengolahan data pendidikan terutama administrasi perkantoran. Hal ini terutama karena masih kurangnya pemahaman para guru akan software-softaware yang dapat membantu dalam administrasi dan juga pemanfaatan dalam pembelajaran. Sedangkan secara spesifik, tujuan yang hendak dicapai adalah:

a. Meningkatkan pemahaman guru tentang peranan software-software dasar MS office dalam pengolahan data pendidikan di sekolah,

b. Meningkatkan pengetahuan guru tentang cara pengolahan data pendidikan yang lebih efektif dan efisien tanpa mengurangi makna teoritisnya.

c. Meningkatkan keterampilan para guru dalam menggunakan Program MS office untuk mengolah data pendidikan terutama data-data administrasi perkantoran yang lebih tersusun.

Berdasarkan analisis awal diketahui bahwa guru masih kurang mengenal aplikasi yang dapat dimanfaatkan dalam proses adminsitrasi seperti MS words, excel, atau power point. Guru hanya menggunakanaplikasi tersebut terbatas pada tools tertentu seperti menulis tanpa adanya numbering, margin, pengiputan data, atau spasi yang benar. Demikian juga pada aplikasi MS excel, guru masih menggunakan apabila form yang seharusnya dilengkap merupakan file berjenis excel. Khusus untuk pemanfaatan MS power point, guru masih sangat asing untuk memanfaatkan animation,menambahkan link, dan video.

\section{METODE}

Tabel 1. Materi yang diberikan dalam workshop

\begin{tabular}{|c|c|c|c|}
\hline $\begin{array}{l}\text { Hari } \\
\text { ke- }\end{array}$ & Materi & Alat dan Bahan & Waktu \\
\hline \multirow[t]{2}{*}{1} & $\begin{array}{l}\text { Microsoft Words } \\
\text { a. Pengenalan tools dalam MS words } \\
\text { b. Penggunaan tools dalam MS word } \\
\text { c. Praktek menulis dan membuattabel dengan MS } \\
\text { words }\end{array}$ & $\begin{array}{l}\text { LCD, Laptop, } \\
\text { komputer }\end{array}$ & 120 Menit \\
\hline & $\begin{array}{l}\text { Microsoft Excel } \\
\text { a. Pengenalan tools dalam MS excel } \\
\text { b. Penggunaan tools dalam MS excel } \\
\text { c. Praktek menulis, penggunaan formula dan } \\
\text { membuat tabel dengan MS excel }\end{array}$ & $\begin{array}{l}\text { LCD, Laptop, } \\
\text { komputer }\end{array}$ & 120 Menit \\
\hline 2 & $\begin{array}{l}\text { Praktek Penyusunan LaporanPerkembangan } \\
\text { a. Pengenalan pengembangan aplikasi } \\
\text { b. MS excel } \\
\text { c. Praktek merekap nilai } \\
\text { d. Praktek menulis deskripsi pada aplikasi MS excel } \\
\text { Evaluasi pelaksanaan } \\
\text { a. Presentasi peserta } \\
\text { b. b. Diskusi kelompok }\end{array}$ & $\begin{array}{l}\text { LCD, Laptop, } \\
\text { komputer . dan } \\
\text { ATK }\end{array}$ & 120 Menit \\
\hline
\end{tabular}

Metode pelatihan yang digunakan dalam kegiatan ini disesuaikan dengan kebutuhan materi, dan tujuan pelatihan. Dengan adanya metode atau cara maka rencana yang telah disusun sebelumnya akan mudah untuk diimplementasikan dalam sebuah kegiatan agar sesuai tujuan dan berhasil dengan maksimal. Kegiatan pelatihan ini dilaksanakan sebanyak 4 kali pertemuan. Satu kali pertemuan berlangsung selama 120 menit. Secara garis besar, kegiatan pelatihan ini dibagi menjadi tiga bagian seperti pada uraian berikut ini beserta materi yang disampaikan pada pelatihan ini. Berikut ini metode yang digunakan dalam selama proses pelatihan ini yaitu:

a. Ceramah

Metode ceramah dapat digunakan ketika materi yang disampaikan berbentuk lisan atau 
verbal dengan media suara dan fasilitator. Metode ceramah digunakan khususnya dalam kegiatan diawal sesi berupa materi secara umum seperti pengenal tools aplikasi.

b. Diskusi

Metode diskusi adalah metode yang memerlukan keterlibatan dua orang atau lebih dan terdapat aktivitas bertukar infromasi secara verbal, keduanya saling berhadapan, saling mempertahankan pendapat dengan tujuan memecahkan sebuah masalah. Penggunaan metode diskusi selama pelatihan digunakan pada saat guru mulaimempraktekan tools dalam aplikasi.

c. Praktek

Pelatihan ini juga memberikan kesempatan kepada para peserta untuk merasakan pengalaman langsung untuk mencoba menggunakan berbagai tools dalam setiap aplikasi. Metode diskusi digunakan dalam kegiatan pelatihan didahului dengan pemberian materi diawal secara verba atau tulisan.

Pada kegiatan pengabadian ini, tim bekolaborasi dengan pihak sekolah SMK Satya Bhakti 2 Jakarta Timur. Dalam kesempatan ini, pihak sekolah menjadi ujung tombak pelaksanaan kegiatan ini. Sekolah sebagai objek sekaligus subjek yang berperan penting dalm kegiatan pelatihan ini. Sekolah juga memfasilitasi guru dalam hal penyediaan sarana dan prasarana terutama keperluan peralatan tulis, kertas dan penggandaan instrument.

\section{HASIL DAN PEMBAHASAN}

Pelaksanaan pelatihan dilaksanakan selama dua sesi dengan teknis yang berbeda. Pada sesi pertama dilakukan dengan pemberian materi dari nara sumber dengan topik tentang seluk beluk Program Microsoft Excel. Sedangkan pada sesi kedua, peserta pelatihan secara bersamasama melakukan workshop penggunaan Program Microsoft Excel dalam kegiatan belajar mengajar seperti pembuatan raport dan lapaoran hasil belajar.

Secara keseluruhan, pelatihan ini berjalan dengan lancar dan memberikan hasil yang baik. Para guru didukung oleh kepala sekolah sangat mendukung kegiatan tersebut. Berikut uraian kegiatan secara terperinci.

\subsection{Kegiatan Pemberian Materi dan Diskusi}

Kegiatan sesi pertama didahului dengan pembukaan oleh kepala sekolah yang memberikan pengarahan akan tujuan adanya pelatihan ini seperti terlihat pada gambar 1 . Kepala sekolah berharap bahwa kegiatan tersebut dapat diikuti dengan baik oleh dewan guru dan dapat memberikan dampak terutama dalam perbaikan proses pembelajaran.

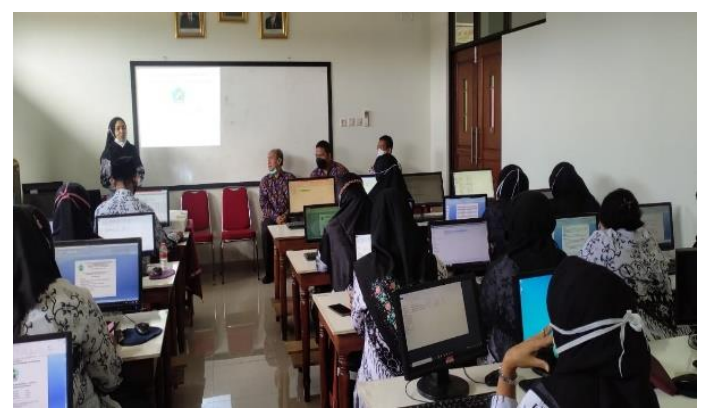

Gambar 1. Pengarahan dari Kepala SMK Satya Bhakti 2 Jakarta Timur

Selanjutnya pemberian materi tentang seputar Program Microsoft Excell yang membahas tentang perlunya guru mengembangkan diri sebagai seorang yang profesional. Dalam hal ini, guru tidak hanya dituntut untuk dapat menyampaikan materi pelajaran agar tercapainya amanat kurikulum, tetapi juga harus berusaha mengembangkan potensi diri melalui salah satunya adalah pelatihan penggunaan aplikasi komputer untuk kelancaran proses belajar mengajar. 
Pemberian materi tidak hanya monolog, tapi dilakukan dialog terutama permasalahanpermasalahan tentang tools dalam program Microsoft Excel. Gambar 2 berikut memperlihatkan penyampaian materi dari narasumber dan kehiatan diskusi yang berjalan dengan baik dan para guru aktif berdiskusi sehingga suasana pelatihan yang cukup dinamis.

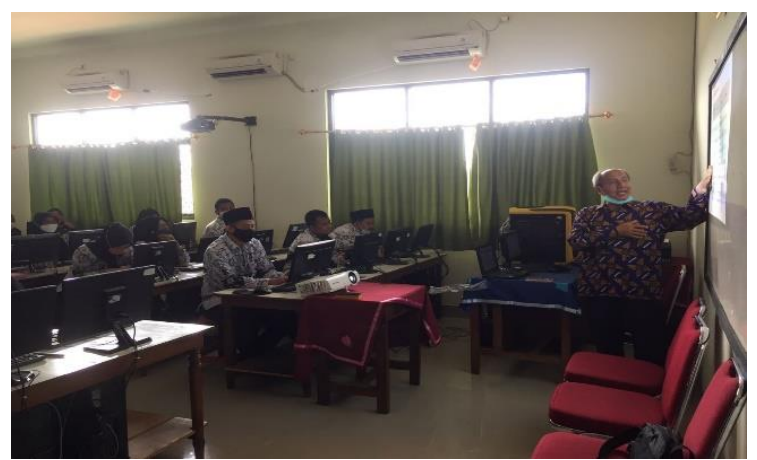

Gambar 2. Penyampaian materi tentang Program Microsoft Excel

Berikutnya disampaikan materi tentang pemanfaatan Program Microsoft Excel untuk pengisian raport siswa. Sebenarnya para guru sedikit banyak sudah memahami teknis-teknis dalam pembuatan raport siswa. Akan tetapi mereka masih belum begitu memahami tentang tools yang spesifik dan pengembangan tool-tool nya. Suasana kegiatan pelatihan sangat kondusif dan nyaman sebagaimana terllihata pada gambar 3 berikut ini.

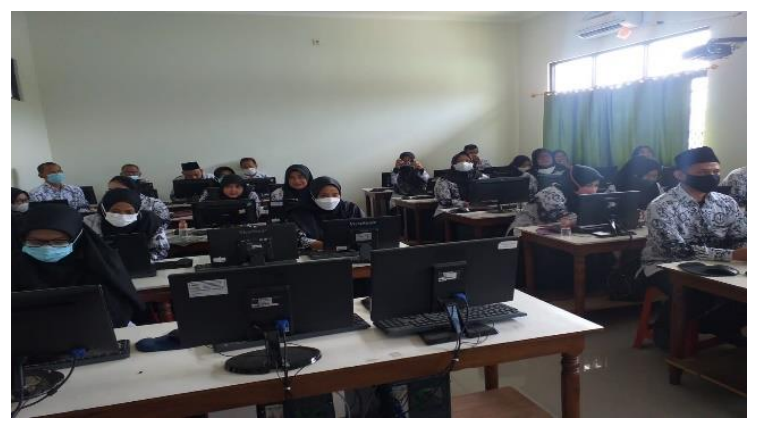

Gambar 3. Suasana pelatihan Program Microsoft Excel

Alasan utama yang diungkapkan para guru adalah waktu yang tidak cukup untuk mempelajari lebih lanjut dengan adanya beban mengajar sebanyak 24 jam. Faktor teknisnya adalah bahwa beberapa guru belum terbiasa dengan perkembangan dunia digital yang semakin pesat dengan banyaknya hal-hal baru. Penyampaian materi ini disambut dengan antusias oleh para guru dengan banyaknya tanggapan dan pertanyaan seputar pemanfaatan Microsoft Excel.

Kegiatan terakhir pada sesi pertama adalah diskusi tentang workshop pemanfaaat toltool dalam Microsoft Excel terutama untuk pengisian raport siswa. Diskusi pada sesi terakhir ini diikuti dengan baik oleh para guru bahkan mereka mengharapkan untuk pelatihan lebih lanjut.

\subsection{Kegiatan Workshop Penggunaan Microsoft Excell}

Sebelum dilakukan workshop, guru-guru menyatakan masih mengalami kesulitan dalam memahami tool-tool dalm Microsof Excel terutama penggunaan rumus matematikanya. Hal ini disebabkan para guru jarang menggunakan Program Microsoft Excel dalam aktivitasnya. Hanya sesekali saja untuk yang benar-benar perlu diselesaikan dengan Program Microsoft Excel.

Setelah dilakukan pelatihan menggunakan model partisipatif dengan pendampingan intensif (klasikal), guru-guru mulai mampu memahami rumus-rumus dalam Penggunaan Program Microsoft Excel. Selama proses workshop tetap diupayakan terbentuknya interaksi antar guru-guru dan antara guru-guru dengan pendamping dalam bentuk diskusi, tanya jawab, pengarahan dan motivasi sebagimana terlihat dari gambar 4 dan gambar 5 berikut ini. Semua 
peserta tampak antusias, serius, tekun, dan aktif mengikuti kegiatan pelatihan hingga berhasil dalam membuat draft raport siswa.

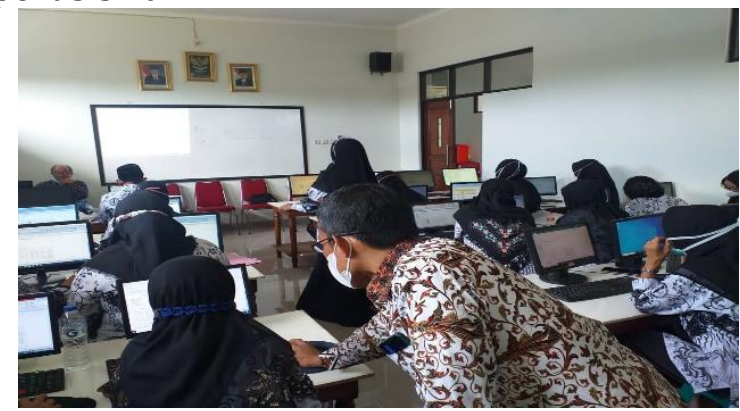

Gambar 4. Pendampingan pelatihan Program Microsoft Excel

Namun demikian apabila dibandingkan dengan kondisi awal sebelum dilakukan tindakan pelatihan dimana guru- guru menyatakan masih kesulitan dalam memahami tools dan rumus Excell nya, setelah diberikan pelatihan dengan model partisipatif dan pendampingan intensif menunjukkan bahwa guru-guru sudah mulai mempunyai pemahaman yang cukup baik tentang Program Microsoft Excel sehingga mampu membuat draft raport siswa.

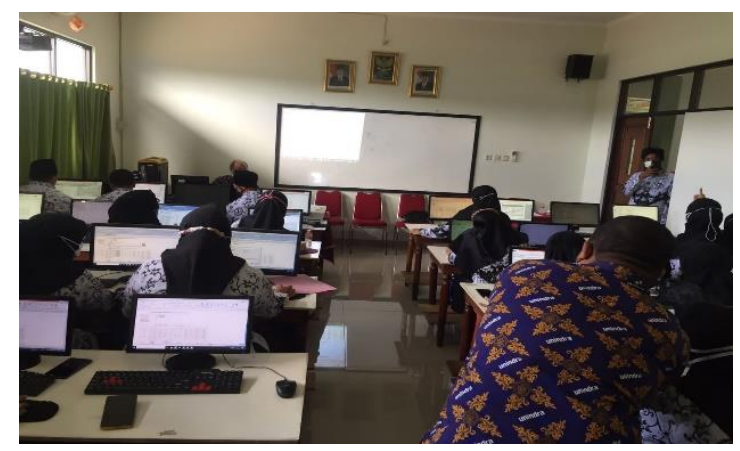

Gambar 5. Pendampingan pelatihan Program Microsoft Excel

\subsection{Hasil yang Diperoleh}

Hasil pelaksanaan kegiatan pengabdian secara keseluruhan dapat dilihat berdasarkan beberapa komponen berikut ini:

1. Ketercapaian target jumlah peserta pelatihan.

Target peserta pelatihan atau khalayak sasaran adalah 37 guru SMK Satya Bhakti 2 Jakarta Timur. Dalam pelaksanaannya kegiatan ini diikuti oleah 33 guru karena ada beberapa yang tidak hadir. Dengan demikian ketercapaian target jumlah peserta pelatihan adalah $90 \%$ atau dapat dinilai baik.

2. Ketercapaian tujuan pelatihan.

Ketercapaian tujuan pelatihan dapat dinilai sangat baik. Dalam kurun dua jam para guru yang mengikuti pelatihan sudah mengusai tools microsoft excel dan dapat mengoperasikan penggunaan rumus dalam menjalankan program tersebut. Terutama dalam penerapan pembuatan buku raport siswa.

3. Ketercapaian target materi yang telah direncanakan.

Ketercapaian target materi yang telah direncanakan pada kegiatan pengabdian ini dapat dinilai baik (93\%). Semua materi yang telah direncanakan dapat disampaikan kepada peserta, meskipun karena keterbatasan waktu ada beberapa materi yang hanya disampaikan secara garis besar.

4, Kemampuan peserta dalam penguasaan materi.

Kemampuan peserta dilihat dari penguasaan materi dapat dinilai baik (87\%). Hal ini dapat dilihat dari kemampuan para guru dalam kegiatan pelatihan dan praktik berupa rumusrumus microsoft excel. Selain itu, antusiasme guru dalam pelatihan berlangsung memberikan beberapa pertanyaan. Selanjutnya peserta pelatihan diberikan latihan terkait dengan pelatihan 
yang telah dilakukan. Diperoleh hasil bahwa semua peserta mampu menyelesaikan tugas yang diberikan. Oleh sebab itu, diharapkan peserta pelatihan dapat memanfaatkan pelatihan ini untuk mampu mengembangkan diri dalam proses pembelajaran terutama dalam pemanfaatan microsoft excel.

\section{KESIMPULAN}

Berdasarkan hasil analisis yang telah dilakukan terkait dengan pengabdian yang telah dilakukan dengan judul pelatihan Program Microsoft Excel untuk pengolahan data pendidikan, tampak bahwa para guru mengungkapkan bahwa pelatihan ini dianggap sebagai workshop yang dapat memberikan ilmu baru dan mereka merasakan bahwa model pelatihan yang mereka dapatkan memberikan informasi yang sangat berharga karena mereka belum pernah mendapatkan pelatihan semacam ini sebelumnya terutama Program Microsoft Excel.

Salah satu bentuk perubahan tingkah laku berdasarkan pelatihan yang telah diberikan, terlihat dengan kemampuan mereka terkait dengan apa yang telah didapatkan dalam pelatihan selain itu dapat memberikan efek yang baik kepada guru itu sendiri sehingga guru yang mendapatkan pelatihan dapat mengembangkan diri dan mampu memahami beberapa hal terkait dengan tugas yang diamanahkan selama ini.

Dengan melihat proses dan hasil pelatihan maka dapat diambil langkah selanjutnya untuk melakukan perbaikan adalah perlunya pelatihan dengan menggunakan aplikasi lainnya guna untuk memberikan informasi dan meningkatkan keterampilan guru dalam pembuatan administrasi di sekolah terutama di zaman yang serba digital sekarang ini.. Selain itu, para guru harus terus diberikan motivasi, sehingga terpacu untuk terus melakukan perbaikan dan inovasi dalam proses pembelajaran.

\section{UCAPAN TERIMA KASIH}

Kegiatan pengabdian ini tidak dapat berjalan dengan baik tanpa dukungan dari pihak sekolah sebagai mitra. Terima kash atas kesempatan dan kerja sama yang baik disampaikan kepada pihak SMK Satya Bhakti 2 Jakarta Timur

\section{DAFTAR PUSTAKA}

Aka, KA. (2017). Pemanfaatan Teknologi Informasi dan Komunikasi (TIK) Sebagai Wujud Inovasi Sumber Belajar di SD. Jurnal Pendidikan dan Pembelajaran DiSD. 1(2a) 2a.

Mugara, R. (2011). Meningkatkan Kompetensi Guru Melalui Penguasaan Teknologi Informasi dan Komunikasi (TIK). Prodi Pengembangan Kurikulum. Bandung: Universitas Pendidikan Indonesia.

Sanjaya, W. (2010). Strategi Pembelajaran Berorientasi Standar Proses Pendidikan. Jakarta: Kencana

Sulistyanto, Hermawan. (2017). PAKOM Pelatihan Pengoperasian Komputer Bagi Perangkat Desa di Kecamatan Gondangrejo Kabupaten Karanganyar. Warta LPM, 20( 2), September 2017:111-114.

Supriady dan Dharma, IMY. (2019). Pelatihan Aplikasi Microsoft Excel 2013 Bagi Guru-Guru SLB Pambudi Dharma. Competitive 14(1), Juni 2019.

Triyanto, A. (2010). Implikasi Perkembangan Tenologi Komputer dan Internet Bagi Konselor Sekolah. Paradigma No.09 Th. V Januari 2010, ISSN 1907-297X.

Usodo, B. (2016). Pelatihan Penerapan beberapa Aplikasi dari Microsoft dalam Pembelajaran Bagi Guru-Guru Matematika SMA di Kabupaten Sragen. Jurnal Elektronik Pembelajaran Matematika, 4(9), Hal 743-752 November 2016 


\section{Halaman Ini Dikosongkan}

